\title{
Ph. D. Research in Economics - By Nepali Scholars at Home and Abroad
}

Mangala Shrestha

\section{INTRODUCTION}

The history of research in economic problems of Nepal is not so old. It was only towards the fifties that some scholars undertook research on some aspects of Nepalese economy.

The economic research indicate different information about economic aspects. Studies on such economic aspects advance knowledge on both theoretical significance about society; and help in solving economic problems. The economic research also may comprise different aspects of economic activity such as, economic theory-application of deductive logic to certain hypothesis, analysis of historical evidence, survey type enperical research requiring team work and studies on economic history. These aspects of economic activity is very important for the country like our's.

Though some $\mathrm{Ph} . \mathrm{D}$, research had been conducted earlier in economics yet, regular research of the doctorate level was taken up only after the establishing of Institute of Humanities and Social Sciences. In the year 2024/2025 there were three Ph.D. scholars in economics. At present a number of studies on different aspects of economics haye been conducted by Nepalese scholars during their research works for Ph.D. degrees. But no effort has been made to communicate the knowledge achieved by these scholars. Apart from a few published research works, majority of the scientific research works undertaken in economics have become a limited value. In order to avoid duplication of works a researcher has to know well in advance as to what problems have had been undertaken previously and what were the objectives and research techniques used. If these basic informations were not communicated there is a possibility of duplication of research works which, in turn, may jeopardise the basic objectives of the research. In developed countries many institutions publish regular abstracts of the research works for wider circulation. In Nepal, however, we lack such media or forums that regularly publish the research works or abstracts of these works done both within and outside the country. These paper tries to show a modest attempt in this regard. Th1s paper aims, to identify different areas of economics in which research leading to $\mathrm{Ph} . \mathrm{D}$. by Nepalese scholars were undertaken;

M. Shrestha is a Lecturer in Economics at Research Division, Tribhuvan University, Kirtipur, Kathmandus Nepal. 
and to 1dentify the future areas of research in each discipline under study. However, the important aspect is to highlight the problems perceived by Nepalese scholars in different aspects of Nepalese economy. Studies on these aspects add not only scientific knowledge to the faculty of economics, but also help in solving our local and national economic problems. Therefore, the main purpose lies in communicating the problems and aspects of Nepal as percelved by Nepalese scholars in the field of economics during their research works for $\mathrm{Ph} . \mathrm{D}$. degrees.

\section{DIFFERENT AREAS OF Ph:D. RESEARCH IN ECONOMICS}

a. Agriculture and Related Fields: Nepal is basically an agricultural country. The economic development of the country is mainly depended on the agriculture. Research in agricultural field may provide advancement in this field. Therefore, it is quite natural that many Ph.D. scholars have chosen this field for their research. The different subjects undertaken by different scholars in agricultural field are as follows:

1. "Role of Agriculture in the Economic Development of Nepal" - Bharat Prasad Dhital.

2. "An Evaluation of Agricultural Production System and Alternatives for Small Farms in Nepal" - Bekha Lal Maharjan.

3. "Role of Agricultural Taxation in Nepal's Economic Development" - Laxmi Shrestha.

4. "The Agricultural Inputs Corporation of Nepal: A Study in Organization and Management and Its Impact on Agriculture" - Ms. S. Lohani.

5. "A Study of Agricultural Development Agencies in Nepal" - Tika Prasad Pokharel.

6. "Rural Development in Nepal: A Study of the Impact of Agricultural Modernization Programmes" - Kiran Koirala.

7. "The Nepalese Hill Agro-Ecosystem: A Stimulation Analysis of Alternate Policies for Food Production and Environment Change" - Mahesh Banskota.

8. "The Demand and Supply of Nitrogeneous Fertilizer in Nepal" - T.N. Pant.

9. "Planned and Spontaneous Land Settlement in Nepal: A Study of Two Teral Settlement in the Kanchanpur District" - Durga Prasad Ojha.

10. "Political Implication of the Cooperative System and Tiller Particlpation in Nepal" - Mohan Man Sainju.

11. "Education and Agricultural Efficiency in Nepal" - Som Prasad Pudasaini. 
12. "Human Labour Absorbation in Agriculture: Demand and Supply Profection (A Case Study of Nepal) - Ms. Leela Pathak.

13: "The Dynamics of Field Implementation of the Training and Visits ( $T$ and V) System In Parsa District of Nepal" - Jagadish Prasad Baral.

14. "Land Reform in Nepal" - Nava Raj Chalise.

b. Money and Finance: Till 1966, Nepal had a dual currency system. Both Nepalese and Indian currencies circulated as legal tender money. His Majesty's Government itself used to maintain its revenues and expenditures into two different accounts - Indian currency account and Nepalese currency account. The circulation of Indian currency in large but unknown quantity led different types of adverse consequences. In view of this facts, currency unification came to be a major goal of the monetary authorities for a long period of time. Around 1956, policies for collecting government revenues and dues in Nepalese currency were initiated and eventually expansion of Nepalese currency circulation Act was promulgated in 1957. The provisions of this Act were successfully enforced in stages in different parts of the country in different times and by 1966 , the kingdom as a whole came to have a meno-currency system for the first time in its history. Since April 3, 1960, Nepalese currency was made fully convertible in Indian currency and in September 6, 1961, Nepal Joined the International Monetary Fund and the International Bank for Reconstruction and Development.

The different subjects chosen by different scholars in the field of money and finance is mentioned below:

1. "The Dual Currency System in Nepal" - Bijaya Bahadur Pradhan.

2. "Monetary Policy in Nepal" - Har1 Har Dev Pant.

3. "Money in Nepal (An Analysis of the Growth and Fluctuation in Nepalese Money Stock)"- Sukhadev Shah.

4. "Demand For Money Under Different Socio-Economic Environments: A Comparative Study with Special Reference to Nepal" - Pushkar Raj Reejal.

5. "Industrial Financing in Nepal" - R.S. Mahat.

6. "Monetary Control Techniques in Nepal" - Guna Nidhi Sharma.

c. International Trade: Nepal is a small landlocked country. Its export and import trade is heavily concentrated with India. Since a very long time it has also experienced continuous trade deficit in its balance of payment position. Ti11 now, the trade deficit have been met by the inflow of forelgn ald. Therefore, research in this field is regarded as very necessary. However, some research scholars in this field chose their toplc as below: 


\section{Whole of forelon Irade in the Economle Development of Developing} Countries with Special Reference to Nepal" - Parthibeshwar P. Timilsina.

2. "Some Aspects of Land Locked Nepal's Trade with India (1960-61 to 1969-70)" - Om Kar Lal Shrestha.

3. "Indo-Nepal Trade and Economic Relations" - P.N. Banskota.

d. Planning: Development planning was introduced in Nepal for the first time in 1956. However, in the absence of a perspective plan, there were no clear cut guidelines within which short term plans could be formulated. In this regard, some of the scholars attempt to present their views and conclusions in their dissertations mentioned below:

1. "Planning for Development in Nepal: A Perspective for 1965 to $1980 "$ - Bekh Bahadur Thapa.

2. "Nepal's Central Planning Organization: An Analysis of Its Effectiveness in an Inter-Organizational Environment" - Devendra Raj Pandey.

e. Public Finance, Public Enterprise and Industrial Development: As elsewhere in the developing part of the world, public expenditure in Nepal has shown an ever increasing tendency. The increasing size of public expenditure fustifies studies pertaining to its size and character. Some of the important research in this field is as mentioned below:

1. "A. Study of Public Expenditure in Nepal" - M.S. Lohani.

2. "Public Enterprise in Nepal: Its Financial Performance in Relation to Government Budget" - Narayan Khadka.

3. "Pricing Policy of Public Enterprises in Nepal" - Jaya Krishna Pathak.

4. "Problems and Potentialities of Industrial Development in Western Region of Nepal" - Narayan Dutta Nepal.

5. "Industrial Flnancing in Nepal" - Ram Saran Mahat.

6. "Resource Mobilization and Economic Development in Nepal During the Plan Period" - Hari Bansha Jha.

f. Population: It is impelling to note that in spite of the close inter-relationship between demographic, economic and soctal factors, economist in Nepal have, by and large refrained from taking up population studies except marginally, as though for want of something elsemore interesting at hand. The following attempt of research had made in the field of population by Nepalese Ph.D. researches:

1. "Population Dynamics of Nepal: An Analytical Study" - Mrigendra Lal Singh. 
2. "Fertility and the Value of Children: A Study of Rural and Urban Population in Nepal."

8. Education: As regards the education field in economics, only one research has been conducted.

1. "Cost-benefit Analysis of Education: A Case Study of Nepal" -

Nirmal Prasad Pandey.

h. Economic Development: Economic development plays a vital role in the al round development of a country. In the field of economic development one Nepalese scholar has chosen the field.

1. "Economic Development of Nepal" - Prafulla Kumar Kafle.

The table regarding the fields of researches in economics and affiliated country for those researches were as follows:

Different Fields of Ph:D: Researches in Economics (2030-41)

\begin{tabular}{|l|c|c|c|c|c|c|c|}
\hline $\begin{array}{l}\text { Degree award-1 } \\
\text { Field of country } \\
\text { Research }\end{array}$ & Nepal & England & India & $\begin{array}{l}\text { Soviet } \\
\text { Russia }\end{array}$ & $\begin{array}{l}\text { Philip } \\
\text { pines }\end{array}$ & U.S.A. & Total \\
\hline $\begin{array}{l}\text { 1. Agriculture and } \\
\text { Related Field }\end{array}$ & 1 & - & 5 & - & 1 & 7 & 14 \\
$\begin{array}{l}\text { 2. Money and Finance } \\
\text { 3. International } \\
\text { Trade }\end{array}$ & - & - & 4 & - & - & 3 & 7 \\
4. Planning & - & - & 1 & 1 & - & 1 & 3 \\
5. Public Finance \\
$\begin{array}{l}\text { Public Enterprise } \\
\text { and Industrial }\end{array}$
\end{tabular}

The above table shows that the highest number of Ph.D. researches in Economics were conducted in affiliation with Indian Universities. The number of Ph.D. researches in Economics from Nepal's university were very few, though may candidates were registered every year of Ph.D. The main reason of being low production of Ph.D. level manpower from Nepal is due to the lack of proper academic atmosphere in Tribhuvan University. 
The academic council meeting held in the year 2026/27 remarked that only one research scholar so far had awarded Ph.D. degree from T.U., though many persons had registered for the same. The reasons for unsatisfactory work in this regard, were lack of proper academic atmosphere of competent supervisors and unavallability of books and materials (Shakya: 1984). This was the reason for large drop-out in the $\mathrm{Ph} . \mathrm{D}$. researches every year.

\section{CONCLUSION}

To set priorities in research in economics is a very difficult task. Every research in economics is directly related to the identification of national objectives. Unless our national objective is specified clearly, no pragmatic and relevant priorities can be set up in the field of economic research. The potential areas for research should be identified. Training on research methodology should be made available to all the teachers of university. Emphasis should be given to applied research in economics. Research policies and programmes should be consistent with the development objectives of the country. Besides, Tribhuvan University should provide all research publications of various agencles, institutes and organizations within and outside university, and it should attempt to preserve published and unpublished theses in economics of all Nepalese scholars through the Research Division or Faculties.

To inspire $\mathrm{Ph} . \mathrm{D}$. researchers in Nepal, proper academic atmosphere should be developed by Tribhuvan Uniyersity and at the same time competent supervisors, books, and materials should be provided by University.

\section{References Cited}

A Survey of Research in Economics: Vol. I and II, ICSSR, India.

Shakya, Soorya Bahadur: Establishing and Development of Tribhuvan University (1955-1973), Research Division, Rector's Office, T.U., 1984.

T.U. Journal: Research in Economics, Vol. X, No. 1, Research Division, Rector's office, T.U., 1978. 